University of Nebraska - Lincoln

DigitalCommons@University of Nebraska - Lincoln

\title{
Biotransformation of Ni-Substituted Hydrous Ferric Oxide by an $\mathrm{Fe}(\mathrm{III})-$ Reducing Bacterium
}

James K. Fredrickson

Pacific Northwest National Laboratory, jim.fredrickson@pnl.gov

John M. Zachara

Pacific Northwest National Laboratory

Ravi K. Kukkadapu

Pacific Northwest National Laboratory, ravi.kukkadapu@pnl.gov

Yuri A. Gorby

Pacific Northwest National Laboratory

Steven C. Smith

Pacific Northwest National Laboratory

See next page for additional authors

Follow this and additional works at: https://digitalcommons.unl.edu/usdoepub

Part of the Bioresource and Agricultural Engineering Commons

Fredrickson, James K.; Zachara, John M.; Kukkadapu, Ravi K.; Gorby, Yuri A.; Smith, Steven C.; and Brown, Christopher F., "Biotransformation of Ni-Substituted Hydrous Ferric Oxide by an Fe(III)-Reducing Bacterium" (2001). US Department of Energy Publications. 146.

https://digitalcommons.unl.edu/usdoepub/146

This Article is brought to you for free and open access by the U.S. Department of Energy at DigitalCommons@University of Nebraska - Lincoln. It has been accepted for inclusion in US Department of Energy Publications by an authorized administrator of DigitalCommons@University of Nebraska - Lincoln. 


\section{Authors}

James K. Fredrickson, John M. Zachara, Ravi K. Kukkadapu, Yuri A. Gorby, Steven C. Smith, and Christopher F. Brown 


\section{Biotransformation of Ni-Substituted Hydrous Ferric Oxide by an Fe(III)-Reducing Bacterium}

\author{
JAMES K. FREDRICKSON,* \\ JOHN M. ZACHARA, \\ RAVI K. KUKKADAPU, YURI A. GORBY, \\ STEVEN C. SMITH, AND \\ CHRISTOPHER F. BROWN \\ Pacific Northwest National Laboratory, P.O. Box 999, MSIN \\ P7-50, Richland, Washington 99352
}

The reductive biotransformation of a $\mathrm{Ni}^{2+}$-substituted ( 5 $\mathrm{mol} \%$ ) hydrous ferric oxide (NiHFO) by Shewanella putrefaciens, strain CN32, was investigated under anoxic conditions at circumneutral pH. Our objectives were to define the influence of $\mathrm{Ni}^{2+}$ substitution on the bioreducibility of the HFO and the biomineralization products formed and to identify biogeochemical factors controlling the phase distribution of $\mathrm{Ni}^{2+}$ during bioreduction. Incubations with CN 32 and NiHFO were sampled after 14 and $32 \mathrm{~d}$, and both aqueous chemistry and solid phases were characterized. By comparison of these results with a previous study (Fredrickson, J. K.; Zachara, J . M.; Kennedy, D. W.; Dong, H.; Onstott, T. C.; Hinman, N. W.; Li, S. W. Geochim. Cosmochim. Acta 1998, 62, 3239-3257), it was concluded that coprecipitated/sorbed $\mathrm{Ni}^{2+}$ inhibited the bioreduction of HFO through an undefined chemical mechanism. M ossbauer spectroscopy allowed analysis of the residual HFO phase and the identity and approximate mass percent of biogenic mineral phases. The presence of AQDS, a soluble electron shuttle that obviates need for cell-oxide contact, was found to counteract the inhibiting effect of $\mathrm{Ni}^{2+}$. Nickel was generally mobilized during bioreduction in a trend that correlated with final $\mathrm{pH}$, except in cases where $\mathrm{PO}_{4}{ }^{3-}$ was present and vivianite precipitation occurred. CN 32 promoted the formation of $\mathrm{Ni}^{2+}$-substituted magnetite $\left(\mathrm{Fe}_{2}^{\prime \prime \prime} \mathrm{Fe}_{(1-x)}^{\prime \prime \prime} \mathrm{Ni}_{x}^{\prime \prime} \mathrm{O}_{4}\right)$ in media with AQDS but without $\mathrm{PO}_{4}{ }^{3-}$. The formation of this biogenic coprecipitate, how ever, had little discernible impact on final aqueous $\mathrm{Ni}^{2+}$ concentrations. These results demonstrate that coprecipitated $\mathrm{Ni}$ can inhibit dissimilatory microbial reduction of amorphous iron oxide, but the presence of humic acids may facilitate the immobilization of $\mathrm{Ni}$ within the crystal structure of biogenic magnetite.

\section{Introduction}

As reactive components of soils and sediments, iron oxides can have an important role in controlling the behavior of trace metal cations such as $\mathrm{Ni}$ and $\mathrm{Co}$. For example, metal cations can be strongly sorbed to iron oxide surfaces with thestrength and extent of sorption being a function of factors that include metal cation type, $\mathrm{pH}$, oxide mineralogy, and surface area. Also di-, tri-, and tetravalent metals may

*Correspondingauthor phone: (509)376-7063; fax: (509)376-1321; e-mail: jim.fredrickson@pnl.gov. substitute for Fe to varying degrees in the structures of iron oxides; hence, the fate of the substituting metal cation is intimately tied to reactions controlling the formation and dissolution of the oxide. For example, in recent investigations, we examined the fate of $\mathrm{Co}$ and $\mathrm{Fe}$ in suspensions of a Cosubstituted goethite $\left(\mathrm{CO}_{0.01} \mathrm{Fe}_{0.99} \mathrm{OOH}\right)$ subjected to bioreduction by Shewanella putrefaciens CN32 (2). Co(III) was reduced by the bacterium to $\mathrm{Co}(\mathrm{II})$ at concentrations, relative to $\mathrm{Fe}(\mathrm{II})$, proportional to its mole ratio in the oxide. The extent of solubilization of the bioreduced Co(II) was dependent upon multiplefactors that included buffer type, the presence or absence of $\mathrm{P}$, and the extent of reduction of the $\mathrm{Co}-\mathrm{FeOOH}$. $\mathrm{Co}(\mathrm{II})$ behavior was linked to competitive sorption reactions on the $\mathrm{Co}-\mathrm{FeOOH}$ surface and coprecipitation in biogenic Fe(II) minerals. In similar studies investigating the bacterial reduction of metal-substituted goethites, the rates of bacterial dissolution of $\mathrm{Mn-}, \mathrm{Co}-, \mathrm{Al}-$ or Cr-substituted goethites were slower relative to an unsubstituted goethite (3), and only $\mathrm{Mn}$ and Co were solubilized at concentrations that were congruent with respect to Fe.

Amorphous hydrousiron oxide (HFO) is common in soils and sediments that undergo periodic cycling between oxidizing and reducing conditions and therefore are not subject to processes such as aging, dehydration, or heating that promote transformation to more crystalline phases. Although iron-reducing bacteria (DIRB) such as S. putrefaciens can utilize both crystalline and poorly crystalline iron oxides as electron acceptors (4-7), poorly crystalline iron oxides are more bioavailable relative to crystalline phases and are believed to be the principal forms of Fe(III) reduced by bacteria in anoxic sediments (8). Due to their amorphous structureand relatively high surface areas, poorly crystalline oxides have a high capacity for sequestering metal cations (9-11). However, as amorphous iron oxides convert to more crystalline forms either during aging or exposure to al kaline conditions, the transformation products may have an increased or reduced capacity for trace metal sequestration. Despite the potential importance of these processes, relatively little is known about the fate of associated trace metals during the microbial reduction of HFO (12).

The purpose of this research was to investigate the bioreduction of Ni-substituted HFO $\left(\mathrm{Ni}_{0.05} \mathrm{Fe}_{0.95}\right)$ by S. putrefaciens during anaerobic respiration and the partitioning of theassociated $\mathrm{Ni}^{2+}$ and $\mathrm{Fe}(\mathrm{II})$ into aqueous and solid phases as a function of buffer type and solution composition. The influence of $\mathrm{Ni}^{2+}$ on the bioreduction process is explored along with effects of $\mathrm{PO}_{4}{ }^{3-}$ on biomineralization. Insights are provided into the phases controlling the solubility and, therefore, relative mobility of oxide-associated $\mathrm{Ni}^{2+}$ as the coprecipitate is biologically reduced. This information contributes to the currentunderstanding of the role of bacterially mediated transformations on the cycling of trace metals and the fate of metal contaminants in soils and sediments.

\section{Materials and Methods}

NiHFO was prepared similar to the procedure described by ref 13 using nitrate salts. Following precipitation at $\mathrm{pH} 7$, the NiHFO suspension was "aged" at room temperature under an anoxic atmosphere for approximately 13 months. The $\mathrm{Ni}^{2+}$ content of the final product was $5 \mathrm{~mol} \%$ or $0.05 \mathrm{~mol}$ of $\mathrm{Ni}^{2+} / \mathrm{mol}$ of $\mathrm{Fe}$. This value was well below the overall sorption capacity of HFO (0.2 mol/mol Fe) (14). The nitrate concentration in the solution was reduced to $<1 \mathrm{mg} \mathrm{L}^{-1}$ nitrate by extensive washing with anoxic $0.1 \mathrm{~mol} / \mathrm{L} \mathrm{NaClO}_{4}$. 
Triplicate anoxic NiHFO (50 mmol of Fe(III)/L) suspensions were $\mathrm{pH}$ adjusted to range from $\mathrm{pH} 6.0$ to $\mathrm{pH} 9.0$ in 0.5 -unit increments using dilute anoxic $\mathrm{HCl}$ or $\mathrm{NaOH}$. Two electrolyte solutions were utilized: (i) $28 \mathrm{mmol} / \mathrm{L} \mathrm{NH}_{4} \mathrm{Cl}, 30$ $\mathrm{mmol} / \mathrm{L}$ lactate, and $50 \mathrm{mmol} / \mathrm{L} \mathrm{NaClO}_{4}$ or (ii) the same as i but including $4.3 \mathrm{mmol} / \mathrm{L} \mathrm{P}$ (as $\mathrm{NaH}_{2} \mathrm{PO}_{4}$ ). The $\mathrm{pH}$ was adjusted on day 1 and readjusted on day 2 , the aqueous phase was sampled for $\mathrm{Ni}^{2+}(\mathrm{aq})$ and $\mathrm{PO}_{4}{ }^{3-}$, and the final $\mathrm{pH}$ was determined on day 3 . The suspensions were mixed at 30 ${ }^{\circ} \mathrm{C}$ and $100 \mathrm{rpm}$. Phase separation was accomplished by transferring $3 \mathrm{~mL}$ of suspension to a syringe fitted with a $0.2-\mu \mathrm{m}$ syringe filter unit. The first $1 \mathrm{~mL}$ of filtrate was discarded, and theremaining filtratewas collected for analysis of $\mathrm{Ni}^{2+}(\mathrm{aq})$ and $\mathrm{PO}_{4}{ }^{3-}$ by ICP-MS. The experiment was conducted and sampled under an anoxic atmosphere to mimic the conditions of other experiments.

Anoxic suspensions of S. putrefaciens strain CN32 were prepared and used in a manner identical to previous research (7). Media components included (in mmol/L): $\mathrm{NH}_{4} \mathrm{Cl}, 28$; $\mathrm{KCl}, 1.34 ; \mathrm{CaCl}_{2}, 0.68 ; \mathrm{NaClO}_{4}, 50$; lactate, 30; $\mathrm{NaH}_{2} \mathrm{PO}_{4}, 0$ or 4.3; and AQDS, 0 or 0.1 . Buffers were either $30 \mathrm{mM} \mathrm{NaHCO}_{3}$ or PIPES, and headspace atmospheres were either $100 \% \mathrm{~N}_{2}$ (PIPES) or $80: 20 \% \mathrm{~N}_{2}: \mathrm{CO}_{2}\left(\mathrm{NaHCO}_{3}\right)$. The media were filter sterilized using a $0.2-\mu \mathrm{m}$ syringe filtration system after $\mathrm{pH}$ adjustment to 6.8 with $\mathrm{NaOH}$.

Samples of the aqueous phase were obtained under an anoxic atmosphere by directly combining $1 \mathrm{~mL}$ of $0.2-\mu \mathrm{m}$ suspension filtrate with $1 \mathrm{~mL}$ of anoxic $1 \mathrm{~mol} / \mathrm{L} \mathrm{HCl}$. Sorbed $\mathrm{Fe}(\mathrm{II})$ and $\mathrm{Ni}^{2+}$ and weak acid-soluble $\mathrm{Fe}(\mathrm{II}) /(\mathrm{III})$ and $\mathrm{Ni}^{2+}$ were obtained by combining $0.2 \mathrm{~mL}$ of suspension with 3.8 $\mathrm{mL}$ of anoxic $0.53 \mathrm{~mol} / \mathrm{L} \mathrm{HCl}$, termed the $0.5 \mathrm{~mol} / \mathrm{L} \mathrm{HCl}$ extraction, and incubating at $30{ }^{\circ} \mathrm{C}$ with agitation for approximately $24 \mathrm{~h}$. Phase separation of theweak acid extract was accomplished using a $0.2-\mu \mathrm{m}$ syringe filter. The first 1 $\mathrm{mL}$ of filtrate was discarded. Total $\mathrm{Fe}(\mathrm{II}+\mathrm{III})$ and $\mathrm{Ni}^{2+}$ were obtained by combining $1 \mathrm{~mL}$ of suspension with $0.7 \mathrm{~mL}$ of concentrated Ultrex $\mathrm{HCl}$, termed the $5 \mathrm{~mol} / \mathrm{L} \mathrm{HCl}$ extraction. Complete dissolution of the solid phase in $5 \mathrm{~mol} / \mathrm{L} \mathrm{HCl}$ was achieved within $24 \mathrm{~h}$. The suspension $\mathrm{pH}$ was determined under an anoxic atmosphere using a glass combination $\mathrm{pH}$ microelectrode (Microelectrodes, Inc., Bedford, $\mathrm{NH}$ ).

To probe whether $\mathrm{Ni}^{2+}$ could potentially inhibit Fe(III) reduction by $\mathrm{S}$. putrefaciens $\mathrm{CN} 32$, two experiments were conducted, one with Fe(III)-nitrilotriacetic acid (NTA), a soluble form of Fe(III) that is readily reduced by $\mathrm{CN} 32$, and unsubstituted HFO, also readily reduced by CN32. For the experiments evaluating the effect of $\mathrm{Ni}$ on $\mathrm{Fe}(\mathrm{III})-\mathrm{NTA}$ reduction, cultures consisted of $\mathrm{CN} 32$ at a cell concentration of $3 \times 10^{8}$ cells $\mathrm{mL}^{-1}, 10 \mathrm{mmol} / \mathrm{L} \mathrm{Fe}(\mathrm{III})-\mathrm{NTA}, 30 \mathrm{mmol} / \mathrm{L}$ each sodium lactate, and $\mathrm{pH} 7$ bicarbonate buffer. Treatments consisted of untreated cells and Fe(III)-NTA with or without the concurrent addition of $0.5 \mathrm{mmol} / \mathrm{L} \mathrm{Ni}$, as $\mathrm{NiCl}_{2} \cdot 6 \mathrm{H}_{2} \mathrm{O}$, and CN 32 cells preincubated in $0.5 \mathrm{mmol} / \mathrm{L} \mathrm{Ni}^{2+}$ solution for $2 \mathrm{~h}$ and washed $1 \times$ in $\mathrm{pH} 7$ bicarbonate buffer and either $\mathrm{Fe}(\mathrm{III})-\mathrm{NTA}$ or $\mathrm{Fe}(\mathrm{III})-\mathrm{NTA}$ with $0.5 \mathrm{mmol} / \mathrm{L} \mathrm{Ni}^{2+}$. A similar experiment was conducted with $50 \mathrm{mmol} / \mathrm{L} \mathrm{HFO}$ substituting for the Fe(III)-NTA.

Theconcentrations of Fe(II) and Fe(total) weredetermined on all bioreduced and control samples using the ferrozine assay $(15,16)$. The determination of $\mathrm{Fe}(\mathrm{II})$ in samples was accomplished within $2 \mathrm{~h}$ of sampling. The concentrations of $\mathrm{Ni}$ and Fe were also determined using ICP-MS.

Mossbauer Spectroscopy. Random orientation absorbers were prepared by mixing 17-28 mg of dried sample, prepared by filtering solids from suspensions and washing with acetone, with petroleum jelly in a 0.5 or $3 / 8$ in. thick and 0.5 in. i.d. Cu holder sealed at one end with clear scotch tape. The sample space was filled with petroleum jelly, and the ends were sealed with the tape. The bioreduced samples werehandled under an anaerobic atmosphere. Spectra were

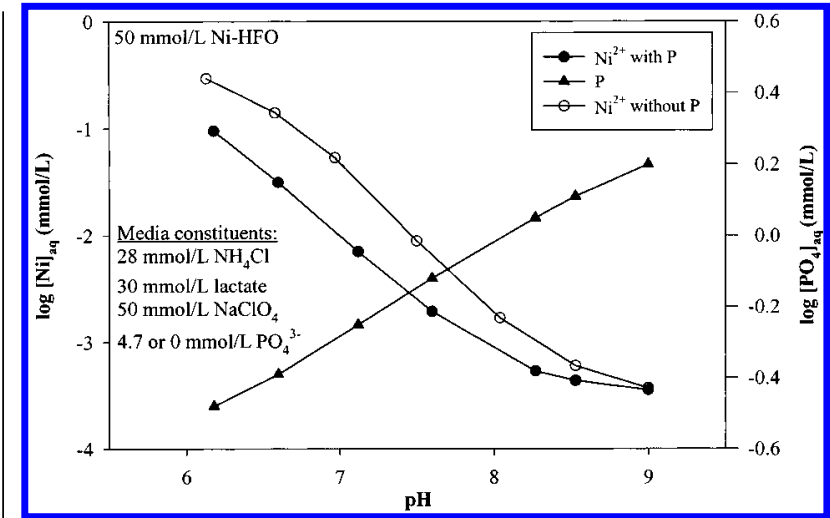

FIGURE 1. Solubility of $\mathrm{Ni}^{2+}$ in contact $w$ ith $\mathrm{NiHFO}(50 \mathrm{mmol} / \mathrm{L})$ and major media components as a function of $\mathrm{pH}$ in the presence and absence of added $\mathrm{PO}_{4}{ }^{3-}(4.7 \mathrm{mmol} / \mathrm{L})$.

collected at room temperature (RT) using $\sim 50 \mathrm{mCi}(1.85 \mathrm{MBq})$ (initial strength) ${ }^{57} \mathrm{Co} / \mathrm{Rh}$ single-line thin sources. The Mössbauer bench (MB-500; WissEL, Germany) was equipped with a dual Mössbauer drive system to gather data simultaneously for two experiments. The velocity transducer (MVT1000; WissEL) was operated in the constant-acceleration mode $(23 \mathrm{~Hz}, \pm 10 \mathrm{~mm} / \mathrm{s})$. Data were acquired on 1024 channels and then folded to 512 channels to give a flat background and a zero-velocity position corresponding to the center shift (CS or $\delta$ ) of a metallic iron foil at room temperature. Calibration spectra were obtained with a 20$\mu \mathrm{m}$-thick $\alpha$-iron foil (Amersham, England) placed in exactly the same position as the samples to minimize any error due to changes in geometry. The transmitted radiations were recorded with $\mathrm{Ar}-\mathrm{Kr}$ proportional counters. The unfolded spectra obtained were folded and evaluated with the Recoil program (U niversity of Ottawa, Canada) usinga Voigt-based hyperfine parameter distribution method (17).

The Mössbauer spectrum measured at room temperature (see Figure 1a in Supporting Information) showed a symmetric doublet $\left(\delta=0.36 \mathrm{~mm} / \mathrm{s}\right.$ and $\left.\Delta \mathrm{E}_{\mathrm{q}}=0.69 \mathrm{~mm} / \mathrm{s}\right)$ indicative of a poorly crystalline material. The Mössbauer spectrum is sensitiveto the presence of goethite and hematite, and the presence of thesecrystallinephases was not observed. $X$-ray diffraction analyses also revealed lower crystallinity of the NiHFO, with evidence of only $2-3$ broad lines in its spectrum (see Figure $1 b$ in Supporting Information). The peaks at $35.5^{\circ}$ and $62.5^{\circ}$ were from HFO. More crystalline ferrihydrites have six lines in their XRD patterns.

\section{Results}

Chemical Behavior of the NiHFO. Previous studies have shown that coprecipitated metals with and adsorbed metals on HFO behave comparably in terms of adsorption/ desorption behavior (14). Phosphate $(4.7 \mathrm{mmol} / \mathrm{L})$ added to the incubation media sorbed to the NiHFO (Figure 1). Its sorption behavior was characteristic of an anion, increasing with decreasing $\mathrm{pH}$ and increasing positive surface charge on the sorbent (14). At pH 7.15, the initial $\mathrm{PO}_{4}{ }^{3-}$ concentration of $4.7 \mathrm{mmol} / \mathrm{L}$ was decreased to $0.58 \mathrm{mmol} / \mathrm{L}$ by adsorption. Thecoprecipitated $\mathrm{Ni}^{2+}$ showed contrasting behavior to $\mathrm{PO}_{4}{ }^{3-}$ but typical of that of a cationic metal (14), with sorption increasing with increasing $\mathrm{pH}$ (Figure 1 ). A one-unit variation in $\mathrm{pH}$ in the circumneutral $\mathrm{pH}$ region leads to a log unit change in $\mathrm{Ni}^{2+}(\mathrm{aq})$. The presence of media $\mathrm{PO}_{4}{ }^{3-}$ decreased $\mathrm{Ni}^{2+}(\mathrm{aq})$ concentrations maintained by the HFO (Figure 1) by approximately $0.5 \mathrm{log}$ unit, indicating an increase in $\mathrm{Ni}^{2+}$ sorption/ retention by the solid phase. This enhanced $\mathrm{Ni}^{2+}$ sorption may result from an increase in negative surface charge density resulting from sorbed $\mathrm{PO}_{4}{ }^{3-}$; ternary surface complex formation between $\mathrm{FeOH}$ surface sites, $\mathrm{PO}_{4}{ }^{3-}$ and 


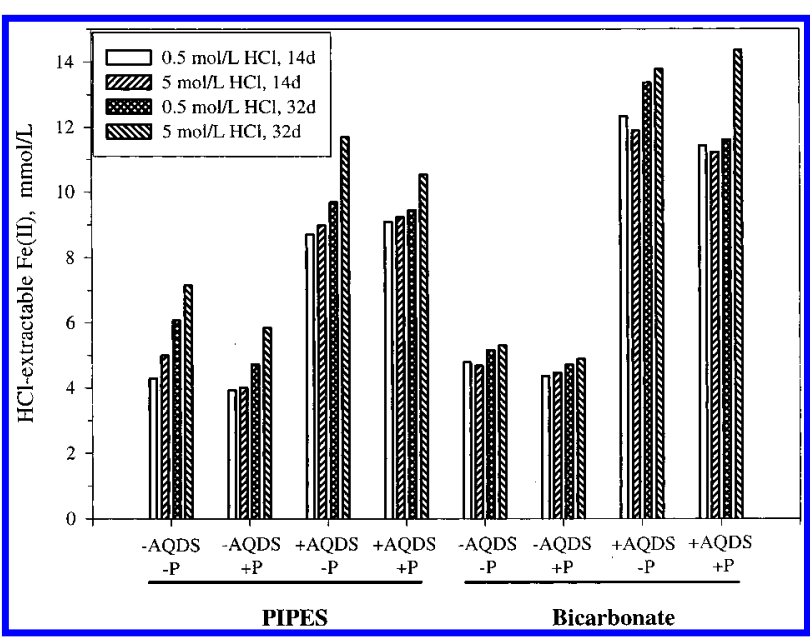

FIGURE 2. Concentration of $\mathrm{Fe}(\mathrm{II})$ in 0.5 and $5.0 \mathrm{~mol} / \mathrm{L} \mathrm{HCl}$ extracts of bioreduced NiHFO after 14 and after $32 \mathrm{~d}$ incubation at $30^{\circ} \mathrm{C}$.

$\mathrm{Ni}^{2+}$; or surface coprecipitation. Fe(II) sorbs comparably, but more strongly, to $\mathrm{HFO}$ than does $\mathrm{Ni}^{2+}$ (7).

NiHFO Reduction by S. putrefaciens. The extent of bioreduction of $\mathrm{NiHFO}$ was determined by measuring Fe(II) extracted by dilute $(0.5 \mathrm{~mol} / \mathrm{L})$ and strong $(5.0 \mathrm{~mol} / \mathrm{L}) \mathrm{HCl}$. These two extraction methods were employed because a variety of phases can begenerated as a result of bioreduction of $\mathrm{HFO}$, including acid-soluble phases such as siderite $\left(\mathrm{FeCO}_{3}\right)$ and vivianite $\left[\mathrm{Fe}_{3}\left(\mathrm{PO}_{4}\right)_{2} \cdot 8 \mathrm{H}_{2} \mathrm{O}\right]$ and crystalline iron(III) oxides including magnetite $\left(\mathrm{Fe}_{3} \mathrm{O}_{4}\right)$ and goethite $(\alpha-$ $\mathrm{FeOOH}$ ) that are poorly soluble in $0.5 \mathrm{~mol} / \mathrm{L} \mathrm{HCl}$ (18).

Solution composition, buffer type, and the presence of anthraquinone-2,6-disulfonate(AQDS) in particular strongly influenced the extent of NiHFO reduction. The presence of $0.1 \mathrm{mmol} / \mathrm{L}$ AQDS had the most striking effect on NiHFO reduction resulting in a 1.6-3-fold increase in $\mathrm{HCl}$-extractable $\mathrm{Fe}(\mathrm{II})$, regardless of buffer type (Figure 2). The influence of $\mathrm{PO}_{4}{ }^{3-}$ on bioreduction was less extensive but resulted in less $\mathrm{HCl}$-extractable Fe(II) in thosetreatments with AQDS. There was little difference in the amount of $\mathrm{Fe}(\mathrm{II})$ in the 0.5 and 5.0 $\mathrm{mol} / \mathrm{L} \mathrm{HCl}$ extracts at $14 \mathrm{~d}$, but at $32 \mathrm{~d}$ the $5.0 \mathrm{~mol} / \mathrm{L} \mathrm{HCl}$ consistently extracted more Fe(II) than did the more dilute acid (Figure 2). This was particularly pronounced in the PIPES-buffered treatments where 10-19\% more Fe(II) was extracted by the strong acid (Figure 2). In previous studies (7), unsubstituted and unaged HFO was reduced by CN32, in general, to a greater degree than the NiHFO. In the bicarbonate-buffered no-cell controls in this study, $\mathrm{HCl}$ extractable Fe(II) was near the detection limit of the ferrozine assay for the dilutions measured and ranged from 0.09 to $0.23 \mathrm{mmol}$ of $\mathrm{Fe}(\mathrm{II}) / \mathrm{L}$.

The amount of $\mathrm{Ni}^{2+}$ in the $\mathrm{HCl}$ extracts of the bioreduced $\mathrm{NiHFO}$ after $32 \mathrm{~d}$ incubation closely tracked total Fe (II+III) (see Figure 2 in Supporting Information). The proportion of metal, Fe or $\mathrm{Ni}$, extracted by $0.5 \mathrm{~mol} / \mathrm{L} \mathrm{HCl}$ was consistently less than that extracted by $5.0 \mathrm{~mol} / \mathrm{L} \mathrm{HCl}$, but the differences were greatest in those treatments that lacked $\mathrm{PO}_{4}{ }^{3-}$. These results indicated that there was a greater proportion of crystalline mineral phases forming upon incubation, particularly in the absence of $\mathrm{PO}_{4}{ }^{3-}$, and that the $\mathrm{Ni}^{2+}$, to the same extent as for $\mathrm{Fe}(\mathrm{II})$, was being incorporated into the crystalline phases. Consistent with the XRD and Mössbauer spectrum (see Figure 1 in Supporting Information), approximately $99 \%$ of the total $\mathrm{Fe}$ and $94 \%$ of the total $\mathrm{Ni}$ associated with the uninoculated (control) NiHFO were soluble in $0.5 \mathrm{~mol} / \mathrm{L} \mathrm{HCl}$ indicating that the aged material had not undergonesignificant conversion to more crystalline phases.

Bioreduction-Induced Solubilization of Metals. Concentrations of soluble $\mathrm{Ni}^{2+}$ and $\mathrm{Fe}(\mathrm{II})$ were determined, at 14 and $32 \mathrm{~d}$ post-inoculation, on solutions passing a $0.2-\mu \mathrm{m}$ filter. Previous results from experiments investigating the bacterial reduction of freshly precipitated HFO demonstrated that there was no difference in the Fe(II) concentrations of $0.2-\mu \mathrm{m}$ or $1.8-\mathrm{nm}$ filtrates (7). As observed for the $\mathrm{HCl}$ extractable metals, $\mathrm{Ni}^{2+}(\mathrm{aq})$ closely tracked $\mathrm{Fe}(\mathrm{II})(\mathrm{aq})$ but at concentrations ranging from 7 to $23 \%$ of those for Fe(II)(aq) (Figure 3). At both sampling times, the concentrations of soluble metals were higher in the bicarbonate than in the PIPES-buffered solutions, and the presence of $\mathrm{PO}_{4}{ }^{3-}$ consistently resulted in lower $\mathrm{Ni}^{2+}(\mathrm{aq})$ and $\mathrm{Fe}(\mathrm{II})(\mathrm{aq})$. The presence of AQDS did not havea consistent significant effect on the concentration of $\mathrm{Fe}(\mathrm{II})(\mathrm{aq})$ or $\mathrm{Ni}^{2+}(\mathrm{aq})$ as it did on $\mathrm{HCl}$-extractable $\mathrm{Fe}(\mathrm{II})$ (Figure 2). $\mathrm{Fe}(\mathrm{II})$ and total $\mathrm{Fe}$ in unreduced controls were below detection limits ( $<3 \mu \mathrm{mol} /$ L) while $\mathrm{Ni}^{2+}$ ranged from 74 to $109 \mu \mathrm{mol} / \mathrm{L}$

The aqueous concentrations of $\mathrm{Fe}(\mathrm{II})$ and $\mathrm{Ni}^{2+}$ were not well correlated with the total extent of reduction as defined by $\mathrm{HCl}$ extraction (Figure 2). While the treatment exhibiting one of the largest extents of reduction (bicarbonate, +AQDS and $\mathrm{PO}_{4}{ }^{3-}$ ) showed the largest concentrations of $\mathrm{Fe}(\mathrm{II})(\mathrm{aq})$ and $\mathrm{Ni}^{2+}(\mathrm{aq})$ (Figure 3), other treatments showing extensive reduction did not. The treatment showing the second greatest concentrations of $\mathrm{F}(\mathrm{II})(\mathrm{aq})$ and $\mathrm{Ni}^{2+}(\mathrm{aq})$ (Figure 3; bicarbonate, $-\mathrm{AQDS}$ and $\mathrm{PO}_{4}{ }^{3-}$ ) exhibited the lowest extent of

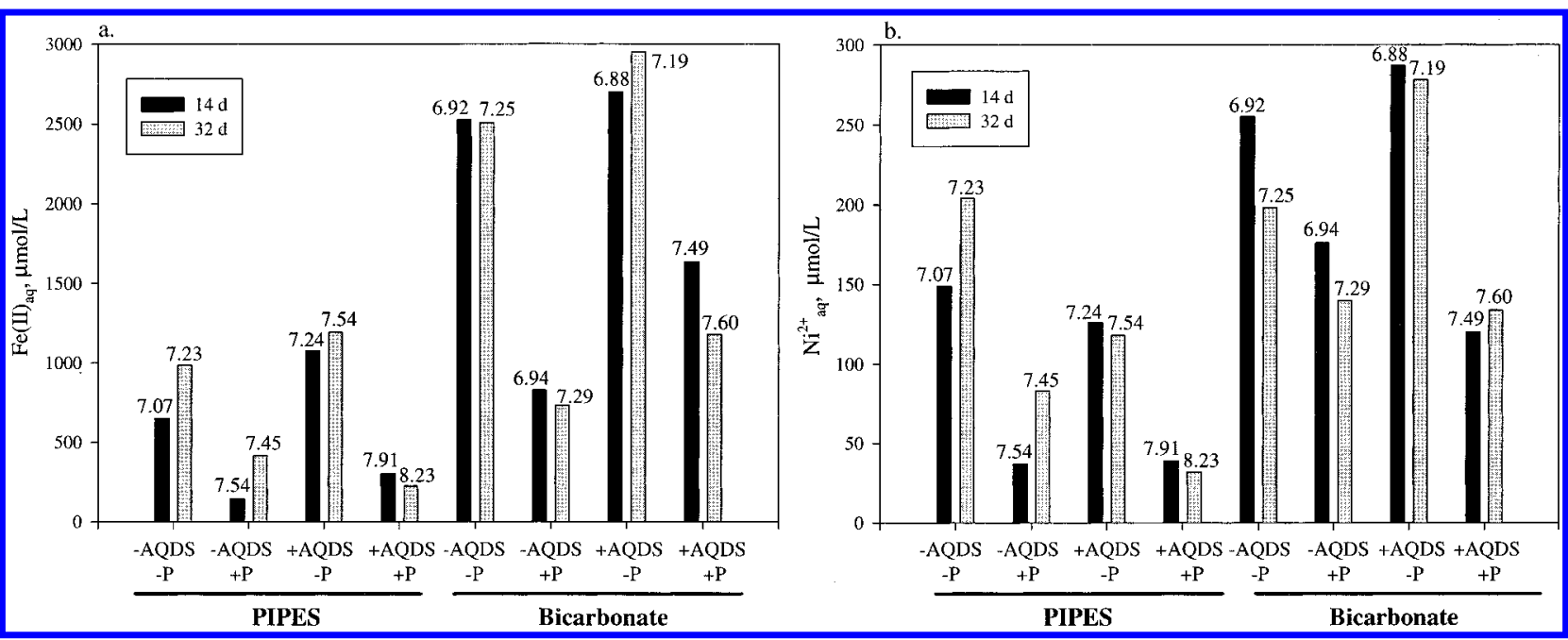

FIGURE 3. Concentrations of aqueous $\left(0.2 \mu \mathrm{m}\right.$ filtered) $\mathrm{Fe}(\mathrm{II})$ and $\mathrm{Ni}^{2+}$ in bioreduced NiHFO suspensions follow ing incubation for 14 and $32 \mathrm{~d}$. Note average final pH values recorded above each treatment. 
bioreduction (Figure 2). A reasonable correlation, however, was noted between $\mathrm{Fe}(\mathrm{II})(\mathrm{aq})$ and $\mathrm{Ni}^{2+}(\mathrm{aq})$ and $\mathrm{pH}$ (note final $\mathrm{pH}$ values in Figure $3 \mathrm{~b}$ ). Consistent with Figure 1, incubations with lower final $\mathrm{pH}$ tended to have higher concentrations of both $\mathrm{Fe}(\mathrm{II})(\mathrm{aq})$ and $\mathrm{Ni}^{2+}(\mathrm{aq})$ than did those with high final $\mathrm{pH}$.

Biomineralization of NiHFO. The XRD analyses of the bioreduced solids revealed extensive biomineralization in sometreatments and little or none in others. Those solutions that lacked $\mathrm{PO}_{4}{ }^{3-}$ but contained AQDS, in either buffer, underwent the greatest biomineralization (Figure 4, panels $\mathrm{b}$ and $\mathrm{f}$ ). The biotransformed NiHFOs contained crystalline solids dominated by magnetite $\left(\mathrm{Fe}_{3} \mathrm{O}_{4}\right)$ or a magnetite-like phase as inferred from the XRD patterns (d spacings). Bioreduced NiHFO in $\mathrm{HCO}_{3}{ }^{-}$buffer without AQDS or $\mathrm{PO}_{4}{ }^{3-}$ showed, apart from broad lines (2-3-lineferrihydrite), peaks dueto 6 -lineferrihydrite and goethite $\left[20^{\circ} 2-\theta ; d_{110}\right]$ indicating microbiologic enhancement of the crystallization of HFO (Figure 4a). An XRD pattern collected on solids from this same treatment after only $14 \mathrm{~d}$ of incubation contained more goethitethan the $32 \mathrm{~d}$ material in (Figure 4a). XRD peaks due to other Fe minerals were not evident except for the $\mathrm{HCO}_{3}{ }^{-}-$ buffered solution containing AQDS and $\mathrm{PO}_{4}{ }^{3-}$ (Figure 4d) whereseveral small but well-defined peaks of siderite $\left(\mathrm{FeCO}_{3}\right)$ and vivianite $\left[\mathrm{Fe}_{3}\left(\mathrm{PO}_{4}\right)_{2} \cdot 8 \mathrm{H}_{2} \mathrm{O}\right]$ were observed. In the PIPESbuffered solution withoutAQDS or $\mathrm{PO}_{4}{ }^{3-}$, there was extensive biomineralization of NiHFO to magnetite or a magnetitelike phase (Figure 4e).

${ }^{57} \mathrm{Fe}$ Mössbauer spectroscopy is a relatively sensitive method for characterizing products, even minor phases, resulting from the bacterial reduction of synthetic and natural iron oxides (19). In contrast to XRD, it provides information on compounds that do not exhibit long-rangestructural order (poorly crystallinematerials) (20). Common Feminerals such as siderite and vivianite are readily distinguished from each other and from magnetite, goethite, etc. (21). Experimental and simulated (Figure 5, panels d and h only) RT Mössbauer spectra of the bacterially reduced NiHFO from the various samplesareshown in Figure 5. An intense doublet dominated the spectra of those treatments that also exhibited modest $\mathrm{Fe}(\mathrm{III})$ reduction (Figure 5, panels a, C, e, and g) as indicated by HCl-extractableFe(II) (Figure2). Their Mössbauer spectra were similar to the doublet for the unreduced NiHFO (see Figure 1 in Supporting Information) although the high energy peak of the ferrous doublet was also evident (noted by *), indicative of $<5 \%$ bioreduction. The spectra for bioreduced $\mathrm{NiHFO}$ samples incubated in bicarbonate or PIPES buffer with AQDS but without $\mathrm{PO}_{4}{ }^{3-}$ (Figure 5, panels $\mathrm{b}$ and f) were characteristic of extensive conversion to magnetite, as indicated by poorly resolved sextets typical of tetrahedral and octahedral Fe in a magnetite-like solid. These spectra also displayed a doublet resulting from unreduced $\mathrm{NiHFO}$ ( $\sim 30 \%$ spectral area in the sample from the PIPES only treatment). Samplesincubated with $\mathrm{AQDS}$ and $\mathrm{PO}_{4}{ }^{3-}$ (Figure 5 , panels $d$ and $h$ ) revealed the presence of vivianite; siderite was also present in the bioreduced NiHFO incubated in bicarbonate buffer with $\mathrm{AQDS}$ and $\mathrm{PO}_{4}{ }^{3-}$ (Figure $5 \mathrm{~d}$ ). Simulations indicated that $30 \%$ of the spectral area in the $\mathrm{HCO}_{3}{ }^{-}$-buffered sample with AQDS and $\mathrm{PO}_{4}{ }^{3-}$ was due to a combination of vivianite and siderite while $10 \%$ of the area in thePIPES buffer with AQDS and $\mathrm{PO}_{4}{ }^{3-}$ was dueto vivianite. Residual NiHFO remained in these treatments at mass concentrations of 70 and $90 \%$, respectively. The two peaks accounting for the vivianite spectra result from two, structurally distinct, Fe(II) site types in vivianite (22).

Transmission electron microscopy of the bioreduced NiHFO in PIPES with $100 \mu \mathrm{M}$ AQDS revealed the presence of randomly distributed nanometer-sized (10-50 nm) crystallites within a matrix of amorphous material (see Figure 3a in Supporting I nformation). Energy dispersive spectroscopy revealed that the crystallites were comprised mainly of Fe with minor amounts of Ni. HRTEM of the crystallites (see Figure $3 \mathrm{~b}$ in Supporting I nformation) provided lattice fringe images with d spacings consistent with those for magnetite or a magnetite-like phase.

Effects of Exogenous Ni on Bacterial Reduction of Fe(III)-NTA and HFO. The extent of NiHFO reduction and biomineralization by S. putrefaciens CN32 in these experiments was lower by 1.6-5.6-fold for all treatments, except PIPES and PIPES with AQDS, than previous studies with HFO that did not contain $\mathrm{Ni}^{2+}$ (7). The extensive difference in the reduction between $\mathrm{HFO}$ with and without $\mathrm{Ni}^{2+}$ prompted investigations into whether the effect was a physiologic or chemical one. In these experiments, the effect of $\mathrm{Ni}^{2+}$ on $\mathrm{Fe}(\mathrm{III})$ reduction was assessed by adding $0.5 \mathrm{mmol} / \mathrm{L} \mathrm{NiCl}_{2}$ to suspensions of CN32 cells that had or had not been preincubated with $\mathrm{Ni}^{2+}$ and incubating with either $\mathrm{Fe}(\mathrm{III})-$ NTA or $\mathrm{HFO}$ in $\mathrm{HCO}_{3}{ }^{-}$buffer. The $\mathrm{Ni}^{2+}(\mathrm{aq})$ concentrations were undersaturated with respect to $\mathrm{Ni}(\mathrm{OH})_{2}(\mathrm{c})$ at the experimental $\mathrm{pH}$ values (using solubility data presented by ref 23).

Thepresence of $0.5 \mathrm{mmol} / \mathrm{L} \mathrm{Ni}^{2+}$ had littleor no inhibitory effect on theinitial rate of reduction of Fe(III)-NTA by CN 32; the rate was $17.5( \pm 0.9) \mu \mathrm{mol}$ of Fe $\mathrm{min}^{-1}$ in the absence of $\mathrm{Ni}^{2+}$ and $16.4( \pm 1.1) \mu \mathrm{mol}$ of Fe $\mathrm{min}^{-1}$ for cultures with $\mathrm{Ni}^{2+}$ (Figure 6). In comparison, preincubation of cells with $\mathrm{Ni}^{2+}$ resulted in lower initial Fe(III) reduction rates; $13.2( \pm 0.5)$ and $11.2( \pm 0.4) \mu \mathrm{mol}$ of Fe $\mathrm{min}^{-1}$ for cultures without and with $0.5 \mathrm{mmol} / \mathrm{L} \mathrm{Ni}^{2+}$, respectively. After $65-70 \%$ of the Fe(III) was reduced in the cultures with $\mathrm{Ni}^{2+}$ preincubation, the rates of $\mathrm{Fe}(\mathrm{III})$ reduction decreased significantly (Figure $6)$ to between $1.2( \pm 0.2)$ and $1.6( \pm 0.3) \mu \mathrm{mol}$ of Fe $\mathrm{min}^{-1}$.

In the experiment with HFO, preincubation of cells with $\mathrm{Ni}^{2+}$ had no impact on $\mathrm{HFO}$ reduction relative to cells not pretreated with $\mathrm{Ni}^{2+}$, while $0.5 \mathrm{mmol} / \mathrm{L} \mathrm{Ni}^{2+}$ added to $\mathrm{HFO}$ suspensions immediately before inoculation with $\mathrm{CN} 32$ cells decreased the extent of reduction of HFO by approximately $50 \%$ at $15 \mathrm{~d}$ (Figure 7). Although the results of the Fe(III)NTA experiment indicated a modest inhibition of Fe(III) reduction by $\mathrm{Ni}^{2+}$ sorbed to cells, the collective results from the Fe(III)-NTA and HFO experiments indicated that the effectswere primarily physicochemical in natureas opposed to a general toxic effect on cells or enzyme inhibition.

\section{Discussion}

Bioreduction of Aged NiHFO. The extent of HFO reduction and the partitioning of biogenic Fe(II) to solution and solid phases in batch CN32 cultures with HFO is a complexprocess that is sensitive to numerous factors including $\mathrm{pH}$, rate of bacterial metabolism, electron donor type, and especially solution ion composition (7). The partitioning of Fe(II) to the aqueous phase and the nature of biominerals have been, in general, consistent with the phases predicted at equilibrium by thermodynamic cal culations. Common biominerals formed from the bacterial reduction of HFO include magnetite, siderite, vivianite, and green rust [iron(II)/iron(III) hydroxide].

The presence of $\mathrm{Ni}^{2+}$ coprecipitated with $\mathrm{HFO}$ at $\sim 5 \mathrm{~mol}$ $\%$ and solution composition strongly influenced the extent of NiHFO reduction and its biomineralization by CN32. In comparison to previous experiments with HFO conducted under essentially identical conditions (7), the extent of reduction of $\mathrm{NiHFO}$ was significantly less, particularly in the bicarbonate buffered solutions and in PIPES with AQDS and $\mathrm{PO}_{4}{ }^{3-}$ (Table 1). Divalent metal cations, such as $\mathrm{Ni}^{2+}$ or Co(II), can slow the kinetics of transformation of HFO to crystalline iron oxides and/or change the composition and properties of theend product (1). $\mathrm{Ni}^{2+}$ and $\mathrm{Co}(\mathrm{II} / \mathrm{III}$ ) suppress the transformation of HFO into goethite and/or hematite, by stabilizing the coprecipitate against dissolution $(24,25)$. 

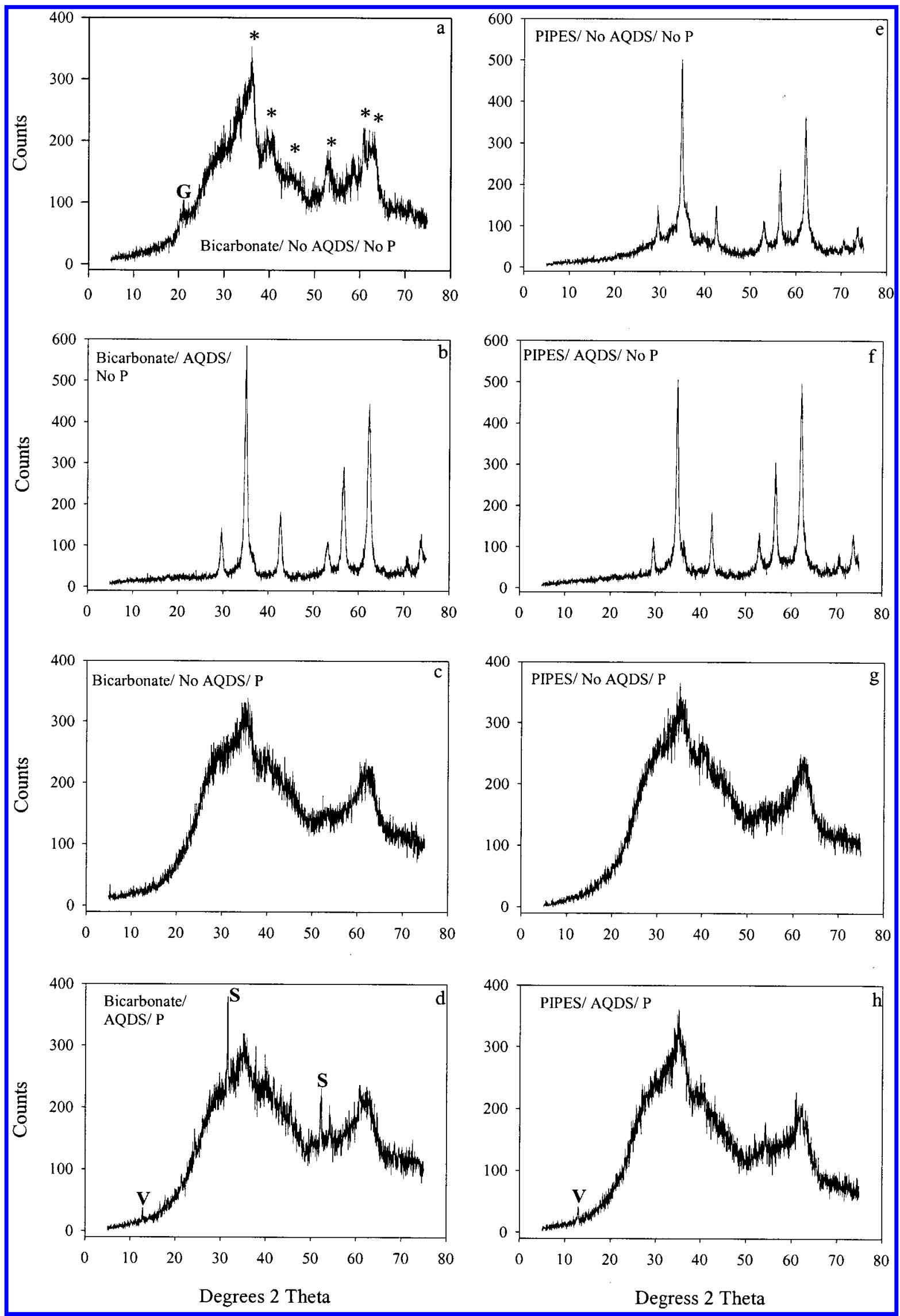

FIGURE 4. Pow der X-ray diffraction patterns of bioreduced NiHFO (32 d) in PIPES or bicarbonate-buffered media $\left(G=\right.$ goethite- $d_{110} *=$ 6-line ferrihydrite peaks, $\mathbf{S}=$ siderite peaks, and $\mathbf{V}=$ vivianite peaks).

$\mathrm{Ni}^{2+}$ was more effective at retarding HFO crystallization than $\mathrm{Co}(\mathrm{II} / \mathrm{III})$ [or $\mathrm{Mn}(\mathrm{II} / \mathrm{III})$ ] and impacted the rate of crystal-

lization in directproportion to its concentration in theNiHFO coprecipitate (24). 


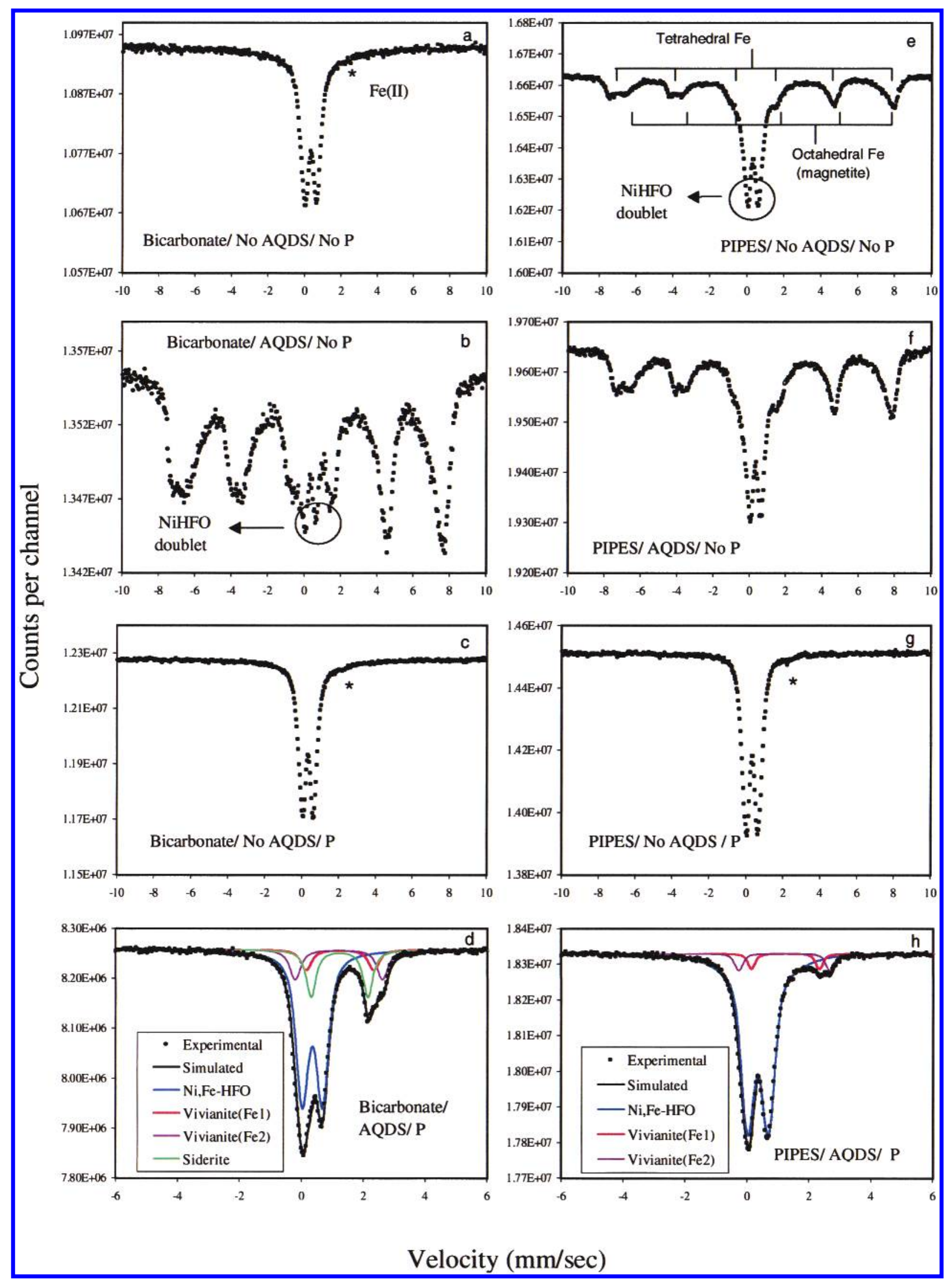

FIGURE 5. Mossbauer spectrum of bioreduced NiHFO (32 d) in PIPES or bicarbonate-buffered solutions.

Although divalent metal cations such as $\mathrm{Zn}^{2+}$ have been shown to function as inhibitors of ferric reductase activity in Azotobacter vinelandii (26), our experiments indicated that the impacts of $\mathrm{Ni}^{2+}$ on the bioreduction of $\mathrm{HFO}$ were not due to noncompetitive inhibition of the biological reduction process. Pretreatment of cells in solutions of $0.5 \mathrm{mmol} / \mathrm{L}$ $\mathrm{NiCl}_{2}$ had little impact on the reduction of either Fe(III)NTA or HFO (Figures 6 and 7). Although the presence of exogenous $\mathrm{Ni}^{2+}$ inhibited Fe(III)-NTA reduction, the effects were much more pronounced for HFO. In this latter 


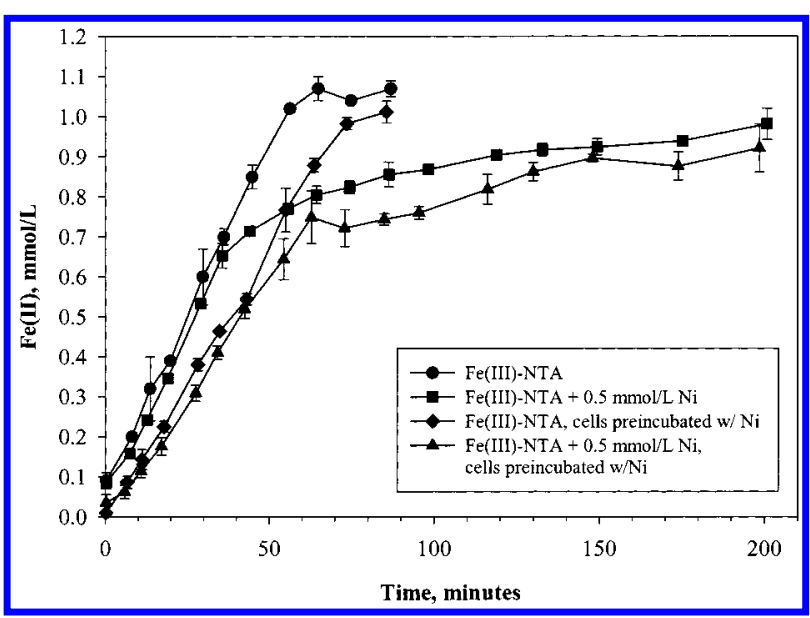

FIGURE 6. Influence of $\mathrm{Ni}^{2+}$ as $0.5 \mathrm{mmol} / \mathrm{L} \mathrm{NiCl}_{2}$ on the reduction of $\mathrm{Fe}$ (III)-NTA by $S$, putrefaciens CN 32 .

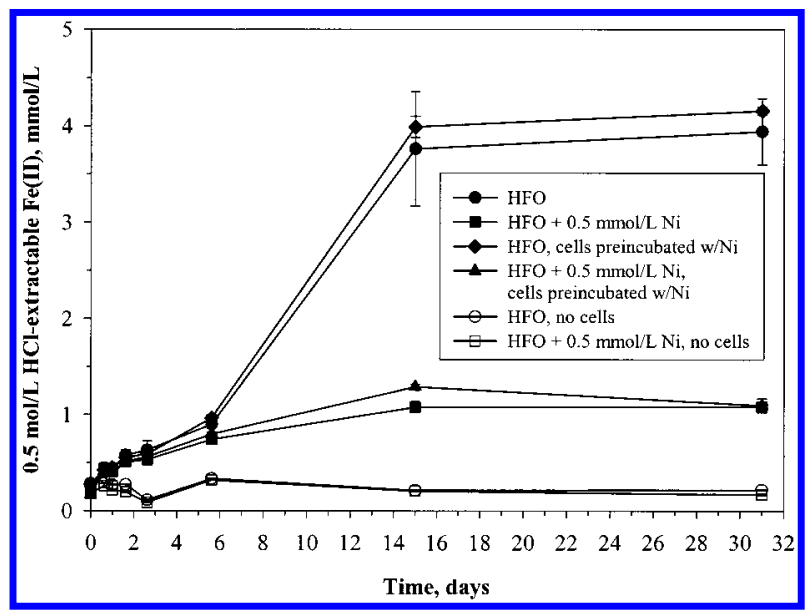

FIGURE 7. Influence of $\mathrm{Ni}^{2+}$ as $0.5 \mathrm{mmol} / \mathrm{L} \mathrm{NiCl}_{2}$ on the reduction of HFO by S. putrefaciens CN32.

experiment, the $\mathrm{Ni}^{2+}$ was strongly sorbed by HFO, indicating that sorbed $\mathrm{Ni}^{2+}$ may block sites on HFO used for electron transduction by DIRB. In contrast, $\mathrm{Ni}^{2+}$, at $100 \mu \mathrm{mol} / \mathrm{L}$, had no effect on the rate or extent of enzymatic reduction of $\mathrm{U}(\mathrm{VI})$ by Desulfovibrio desulfuricans (27). These results point to physical-chemical effects (e.g., surface site blockage, dissolution inhibition) as the dominant factors controlling the extent of NiHFO reduction and biomineralization.

Effects of AQDSand $\mathrm{PO}_{4}{ }^{3-}$ on Bioreduction. Particularly striking were the interactive effects of AQDS and $\mathrm{PO}_{4}{ }^{3-}$ on the bioreduction process; the presence of AQDS significantly enhanced the extent of NiHFO bioreduction regardless of whether $\mathrm{PO}_{4}{ }^{3-}$ was present or not in either buffer (Figure 2) while the presence or absence of $\mathrm{PO}_{4}{ }^{3-}$ markedly influenced biomineralization (Figures 4 and 5). AQDS has previously been shown to function as an electron shuttle between DIRB and iron(III) oxides, facilitating the rate and extent of reduction and relieving the requirement for cell-oxide contact $(4,7,28,29)$. One exception to this was the lack of enhanced reduction of either $\mathrm{Ni}(\mathrm{II})$ - or $\mathrm{Co}(\mathrm{III})$-substituted (at approximately $1 \%$ ) goethite by S. putrefaciens (2). The reason for the lack of enhanced reduction were unclear but may havebeen due to the $\mathrm{Ni}^{2+}$ and $\mathrm{Co}(\mathrm{II} / \mathrm{III})$ blocking goethite surface sites, slowing $\mathrm{AH}_{2} \mathrm{DS}$-facilitated reduction, similar to the ability of strongly sorbing metal cations to inhibit acid dissolution by reducing surface protonation (30, 31).

$\mathrm{AH}_{2} \mathrm{DS}$ because of its relatively high solubility, small size, and low $\mathrm{E}^{\circ}(-184 \mathrm{mV}$ at $\mathrm{pH} 7)$ is a facilereductant of iron(III) oxides and may access surfaces and surface sites that bacteria cannot. The mechanisms by which DIRB reduce solid-phase
Fe(III) are poorly understood. The localization of c-type cytochromes in the outer membrane of S. oneidensis $(32,33)$ suggests that these organisms are able to establish a direct biochemical linkage between their electron transport system and the oxide surfaces. Therefore, the requirement for direct cell-oxide contact $(34,35)$ likely limits electron transfer, and the presence of AQDS or humic acids can partially overcome this limitation until other factors becomelimiting. Although recent research suggests that some Shewanella sp. produce extracellular quinones that can function as electron shuttles (36), the extent to which microbial quinones facilitate iron(III) oxide reduction is unknown.

Fe(II) sorption to oxide and cell surfaces has been implicated as an important factor controlling the rate and extent of bacterial reduction of iron oxides $(5,6)$ and the presence of NTA to promotesolubilization of Fe(II) enhanced the reduction of goethite in direct proportion to its concentration (37). The question therefore arises as to whether AQDS (or $\mathrm{AH}_{2} \mathrm{DS}$ ) can complex Fe(II) and, if so, whether this might have contributed to the enhanced bacterial reduction of iron oxides. Although the concentrations of soluble Fe(II) following bioreduction for 14 or $32 \mathrm{~d}$ were moderately higher in solutions with $\mathrm{AQDS}$ (but without $\mathrm{PO}_{4}{ }^{3-}$ ) than in its absence (Figure 3 ), it is clear that complexation effects could only account for a small fraction of the enhanced NiHFO reduction.

Although thepresence of $\mathrm{PO}_{4}{ }^{3-}$ did not markedly influence the extent of NiHFO reduction (Figure 2 ), it significantly impacted the concentrations of soluble $\mathrm{Fe}(\mathrm{II})$ and $\mathrm{Ni}^{2+}$, lowering their respective concentrations relative to the same treatment without $\mathrm{PO}_{4}{ }^{3-}$ in each case(Figure 3). Theinfluence of $\mathrm{PO}_{4}{ }^{3-}$ on $\mathrm{Fe}(\mathrm{II})$ and $\mathrm{Ni}^{2+}$ solubility is most likely due to adsorption effects (Figure 2 ) and its ability to complex these metals and precipitate as $\mathrm{Fe}_{3}\left(\mathrm{PO}_{4}\right)_{2} \cdot 8 \mathrm{H}_{2} \mathrm{O}$ (vivianite), $\mathrm{Ni}_{3}-$ $\left(\mathrm{PO}_{4}\right)_{2} \cdot 8 \mathrm{H}_{2} \mathrm{O}$, or possibly a mixture of these phases. The presence of vivianite in the bioreduced samples with AQDS and $\mathrm{PO}_{4}{ }^{3-}$ was readily confirmed by Mössbauer spectroscopy (Figure 5, panels $\mathrm{d}$ and $\mathrm{h}$ ). $\mathrm{Ni}^{2+}$ forms isostructural double phosphates, e.g., $\mathrm{Ni}_{3}\left(\mathrm{PO}_{4}\right)_{2} \cdot 8 \mathrm{H}_{2} \mathrm{O}$ (38), and can probably substitute for $\mathrm{Fe}(\mathrm{II})$ in vivianite. In previous studies with Co(II), we precipitated vivianite in the presence of dilute(Fe:Co was 100$) \mathrm{Co}(\mathrm{II})$, removing 99.8 and $98.8 \%$ of the $\mathrm{Fe}(\mathrm{II})$ and Co(II), respectively. The resulting vivianite coprecipitate produced an XRD pattern that was indistinguishable from specimen vivianite (2). $\mathrm{Ni}^{2+}$ is likely to exhibit a behavior similar to $\mathrm{Co}(\mathrm{II})$ given the similarities in their ionic radii.

The most marked effect of $\mathrm{PO}_{4}{ }^{3-}$ was on the biomineralization of NiHFO; in all cases where the bioreduction of $\mathrm{NiHFO}$ resulted in extensive conversion to a magnetite-like mineral (Figures 4 and 5, panelsb, e, and f), the corresponding treatments with $\mathrm{PO}_{4}{ }^{3-}$ lacked any evidence of magnetite (Figures 4 and 5, panels d, g, and h). Magnetite can form rapidly at $\mathrm{pH}$ values at and above neutrality over periods of hours by topotactic conversion of HFO following Fe(II)(aq) sorption $(39,40)$. Magnetite was a common product of HFO bioreduction by CN 32 in PIPESand bicarbonate buffers with AQDS also in the absence of $\mathrm{PO}_{4}{ }^{3-}(7)$. Inorganic phosphate has been shown to severely inhibit theformation of magnetite from the oxidation of $\mathrm{Fe}(\mathrm{II})$ solutions, via a green rust intermediate, by either stabilizing the green rust precursor or inhibiting magnetite crystallization (41). A phosphateto-iron ratio of 0.4 was sufficient to inhibit the nucleation and crystal growth of magnetite from Fe(II) solutions being oxidized by nitrateunder basic conditions (42). I n our NiHFO (or HFO) bioreduction experiments, phosphate, present at a P:Fe ratio of $\sim 0.1$, probably inhibited magnetite formation via similar mechanisms-sorption to HFO and subsequent blockage of $\mathrm{Fe}(\mathrm{II})$ binding or via inhibition of magnetite crystallization. As shown in Figure 1, 88\% of the added $\mathrm{PO}_{4}{ }^{3-}$ was sorbed by the NiHFO at pH 7. It is of interest that the 
TABLE 1. Comparison of Extent of Reduction of HFO and NiHFO by S. putrefaciens CN32 and Nature of Biominerals Formed

\begin{tabular}{|c|c|c|c|c|c|c|}
\hline \multirow[b]{2}{*}{ components } & \multicolumn{2}{|c|}{ nominal $\% \mathrm{Fe}(\mathrm{III})$ reduction ${ }^{a}$} & \multicolumn{2}{|c|}{$\% 0.5 \mathrm{~mol} / \mathrm{L} \mathrm{HCl}(\mathrm{NiHFO})^{c}$} & \multicolumn{2}{|c|}{ phases identified } \\
\hline & $\mathrm{HFO}^{b}$ & NiHFO & $\mathrm{Fe}$ & $\mathrm{Ni}$ & HFO & NiHFO \\
\hline PIPES & 8.0 & 13.2 & 76.8 & 80.6 & magnetite & NiHFO, magnetite \\
\hline PIPES, $\mathrm{P}$ & 29.1 & 10.3 & 91.9 & 91.7 & $\mathrm{pc}^{d^{-}}$ & $\mathrm{NiHFO}$ \\
\hline PIPES, AQDS & 12.8 & 21.2 & 84.6 & 86.0 & magnetite & NiHFO, magnetite \\
\hline PIPES, P, AQDS & 74.2 & 20.6 & 94.1 & 94.4 & green rust & NiHFO, vivianite \\
\hline $\mathrm{NaHCO}_{3}$ & 34.7 & 11.2 & 83.5 & 82.4 & magnetite, siderite & NiHFO, goethite \\
\hline $\mathrm{NaHCO}_{3}, \mathrm{P}$ & 61.5 & 10.3 & 96.3 & 95.0 & siderite, vivianite & NiHFO \\
\hline $\mathrm{NaHCO}_{3}, \mathrm{AQDS}$ & 48.2 & 29.2 & 91.4 & 89.0 & magnetite, siderite & magnetite, NiHFO \\
\hline $\mathrm{NaHCO}_{3}, \mathrm{P}, \mathrm{AQDS}$ & 74.8 & 25.3 & 92.7 & 91.4 & siderite, vivianite & NiHFO, vivianite, siderite \\
\hline
\end{tabular}

NiHFO in the PIPESand bicarbonate buffered solutions with $\mathrm{PO}_{4}{ }^{3-}$ but without AQDS showed no evidence of vivianite by Mössbauer spectroscopy. Mössbauer is capable of detecting vivianite at mass concentrations as little as $1 \%$, despite reduction of $\sim 10 \%$ of the initial Fe(III) concentration (Table 1). The reasons for the lack of vivianite formation in these samples are unclear but are likely due to strong sorption of $\mathrm{P}$ to unreduced NiHFO. As the mass of NiHFO is reduced via bacterial reduction, $\mathrm{PO}_{4}{ }^{3-}$ is released, theFe(II) concentration increases, and the solubility of vivianite is exceeded.

Partitioning of $\mathrm{Ni}^{2+}$ during Bioreduction. The behavior of $\mathrm{Ni}^{2+}$ closely tracked that of Fe in all treatments (Figure 3). The bioreduction of NiHFO reduced the $\mathrm{HCl}$ extractability of Feand $\mathrm{Ni}^{2+}$ to similar degrees (Table 1 ) with the decrease being a function of the extent of bioreduction and mineralization. In treatments where the NiHFO was extensively converted to magnetite (Table 1), the $0.5 \mathrm{~mol} / \mathrm{L} \mathrm{HCl}$ extractable $\mathrm{Fe}$ and $\mathrm{Ni}^{2+}$ was significantly decreased. In treatments where biomineralization was minimal and products, if any, were acid-soluble Fe(II) phases such as siderite and vivianite, the 0.5 and $5.0 \mathrm{~mol} / \mathrm{L} \mathrm{HCl}$ extraction results were in close agreement. The one exception to this was the decrease in the $0.5 \mathrm{~mol} / \mathrm{L} \mathrm{HCl}$ extractability of $\mathrm{Fe}$ and $\mathrm{Ni}^{2+}$ in the bioreduced NiHFO sample from the bicarbonatebuffer without $P$ or AQDS between the 14- and 32- $d$ samplings (Figure 2 in Supporting Information); by day 32, 16-17\% of Feand Ni was not extractable by $0.5 \mathrm{~mol} / \mathrm{L} \mathrm{HCl}$. The decrease in $0.5 \mathrm{~mol} / \mathrm{L} \mathrm{HCl}$ extractability of Feand $\mathrm{Ni}$ in this treatment resulted from the Fe(II) catalyzed formation of goethite and 6-line ferrihydrite (Figure 4a). Both goethite and 6-line ferrihydrite are more resistant to weak acid dissolution than 2-line ferrihydrite.

Wehavefound magnetite generated from the bioreduction of $\mathrm{HFO}$ to be highly soluble in $0.5 \mathrm{~mol} / \mathrm{L} \mathrm{HCl}$ probably due to the relatively small particle size (tens of nanometers) (7), but the rate and extent of acid dissolution of crystallineiron(III) oxides such as magnetite can vary significantly for different specimens of the same oxide (1). Degree of crystallinity, particlesize/ surfacearea, and metal substitution all can influence acid dissolution of iron oxides.

The similarity in behavior of $\mathrm{Ni}$ and Fe suggests that $\mathrm{Ni}^{2+}$ was incorporated into the inverse spinel structure of magnetite. Previous studies have demonstrated that $\mathrm{Ni}^{2+}$ substitutes for $\mathrm{Fe}(\mathrm{II})$, due to similarities in ionic radii and electronegativity, in the octahedral sites of magnetite (24, 42). Diamandescu et al. (43) reported synthesis of $\mathrm{Ni}$ substituted magnetite $\left(\mathrm{Fe}^{\prime \prime \prime}{ }_{2} \mathrm{Fe}^{\prime \prime}{ }_{(1-x)} \mathrm{Ni}^{\prime \prime}{ }_{x} \mathrm{O}_{4}, \mathrm{x}=0.256\right)$. The congruent dissolution of $\mathrm{Ni}^{2+}$ and Fefrom the $0.5 \mathrm{~mol} / \mathrm{L} \mathrm{HCl}$ extracts of samples where extensive biomineralization has occurred and the presence of $\mathrm{Ni}$ as revealed by EDS are indicative of $\mathrm{Ni}^{2+}$ substitution into magnetite and its more or less random distribution within the crystals (1). Cooper et al. (12) suggested that $\mathrm{Zn}^{2+}$, which has an ionic radius of $0.75 \AA$ as compared to $0.70 \AA$ for $\mathrm{Ni}^{2+}$ and $0.74 \AA$ for $\mathrm{Fe}^{2+}$, was incorporated into magnetite during the bioreduction of lepidocrocite $(\alpha-\mathrm{FeOOH})$ with surface-bound $\mathrm{Zn}$ by $\mathrm{S}$. putrefaciens.

Implications for Biomineralization and Trace Metal Mobility. The biomineralization of iron(III) oxides as they undergo reduction by DIRB is a complex process influenced by multiplebiological and chemical factors. Amongthemajor factors controlling Fe biomineralization is the composition and concentration of cations and anions, particularly those that can form complexes with $\mathrm{Fe}(\mathrm{II})(\mathrm{aq})$ or $\mathrm{Fe}(\mathrm{s})$ species or that function as counterions for precipitates (e.g., $\mathrm{CO}_{3}{ }^{2-}$, $\left.\mathrm{PO}_{4}{ }^{3-}\right)$. For example, the presence of $\mathrm{PO}_{4}{ }^{3-}$ and carbonate promoted the formation of vivaniteand siderite, respectively, during the bioreduction of $\mathrm{Co}(\mathrm{III})$ - and $\mathrm{Ni}^{2+}$-substituted goethites (2). In fact, the presence of these inorganic ligands facilitated the reduction of thesubstituted goethites, probably by creating conditions where reduction was thermodynamically favored. In contrast, the current studies revealed that the presence of $\mathrm{PO}_{4}{ }^{3-}$ stabilized NiHFO against mineralization during bioreduction while AQDS (without $\mathrm{PO}_{4}{ }^{3-}$ ) facilitated theconversion to magnetite. Thecurrent studiesalso showed minimal tendency for sideritization in $\mathrm{HCO}_{3}{ }^{-}$buffer, in contrast to our previous findings with unsubstituted HFO (7). The presence of coprecipitated $\mathrm{Ni}^{2+}$ may have slowed reduction, yielding conditionskinetically suited to magnetite formation.

Equally complex are the reactions that influence the solubility of trace metals such as $\mathrm{Ni}$ during the bacterial reduction of HFO coprecipitates. Thebioreduction of $\mathrm{NiHFO}$, in general, resulted in higher concentrations of $\mathrm{Ni}^{2+}(\mathrm{aq})$ [and $\mathrm{Fe}(\mathrm{II})(\mathrm{aq})$ ], particularly in treatments that lacked $\mathrm{PO}_{4}{ }^{3-}$, as compared to unreduced NiHFO. Thus, for non- $\mathrm{PO}_{4}{ }^{3-}$ containing media there was net $\mathrm{Ni}^{2+}$ solubilization. While we have previously discussed the impacts of $\mathrm{pH}$ and $\mathrm{PO}_{4}{ }^{3-}$ on $\mathrm{Ni}^{2+}$ solubility, other factors including carbonate complexation and solid/solution phase changes were influential as well. With respect to the bicarbonate issue, higher concentrations of both $\mathrm{Ni}^{2+}(\mathrm{aq})$ and $\mathrm{Fe}(\mathrm{II})(\mathrm{aq})$ were noted in bicarbonate buffer as compared to PIPES (Figure 3). While multiplecauses were involved, e.g., $\mathrm{pH}$ and reduction extent, carbonate complexation also played a role. For example, the computed solubilities of $\mathrm{Ni}(\mathrm{OH})_{2}(\mathrm{c})$ (using data from refs 23 and 44) were $3.28 \times 10^{-3}$ and $6.46 \times 10^{-4} \mathrm{~mol} / \mathrm{L}$ at $\mathrm{pH} 7.2$ in $30 \mathrm{mmol} / \mathrm{L} \mathrm{HCO}_{3}{ }^{-}$and $30 \mathrm{mmol} / \mathrm{L}$ PIPES buffers, respectively, attesting to the role of bicarbonatecomplexation in $\mathrm{Ni}^{2+}$ solubilization.

In some treatments, bioreduction changed the character of the solid phase. The Ni-sorbing/ host phase was depleted, and biogenic phases were formed with distinctly different and generally lower surface areas, adsorption strengths for $\mathrm{Ni}^{2+}$, and distribution ratiosfor coprecipitation. Our previous studies have shown that biogenic siderite and vivianite crystallites are orders of magnitude larger in size than HFO (7). These phases and magnetite are unlikely to adsorb $\mathrm{Ni}^{2+}$ 
comparably to HFO as their surface areas and chemical affinities for $\mathrm{Ni}^{2+}$ are smaller than HFO. This last point is to a large degree speculative but is supported by related publications (see, for example refs 45-48). In addition to solid phase change, bioreduction has also enriched the aqueous phase with soluble $\mathrm{Fe}(\mathrm{II})$ that competes with $\mathrm{Ni}^{2+}$ for both surface and structural binding sites. Excess Fe(II)(aq) has been shown to suppress Co(II)(aq) sorption to goethite, for example (2). Thus, it is to be anticipated that trace metal solubilization may be a common outcome of bioreduction unless large concentrations of precipitation inducing anions (e.g., $4.7 \mathrm{mmol} / \mathrm{L} \mathrm{PO}_{4}{ }^{3-}$ ) are present.

An interesting comparison that speaks to (i) the comparative effects $\mathrm{Fe}(\mathrm{II})(\mathrm{aq})$ competition and HFO depletion and (ii) the challenge of quantitative interpretation can be made with the treatments presented in Figure 5, panels a (bicarbonate/ no AQDS/ no $\mathrm{PO}_{4}{ }^{3-}$ ) and b (bicarbonate/ AQDS/ no $\left.\mathrm{PO}_{4}{ }^{3-}\right)$. These two experiments displayed comparablefinal $\mathrm{pH}(6.88-7.25)$ and the highest concentrations of $\mathrm{Ni}^{2+}(\mathrm{aq})$ and $\mathrm{Fe}(\mathrm{II})(\mathrm{aq})$ (Figure 3) observed in all treatments. They differed markedly, however, in the composition of their final solid-phase assemblage (Figure 5). The bicarbonate/no AQDS/ no $\mathrm{PO}_{4}{ }^{3-}$ treatment showed no evidence for biomineralization (Figure $5 \mathrm{a}$ ) while the bicarbonate/AQDS/no $\mathrm{PO}_{4}{ }^{3-}$ treatment displayed the largest extent of biotransformation to magnetite (Figure 5b). Despite these dramatic differences, the final $\mathrm{Ni}^{2+}(\mathrm{aq})$ concentrations were almost identical, and correspondingly, so was the $\mathrm{Ni}_{\text {total }} / \mathrm{Fe}_{\text {total }}$ ratio of the solid-phaseresidues, despitetheir different mineralogic composition. Speciation and solubility calculations showed that these final concentrations were over an order of magnitudebelow thosesaturated with $\mathrm{Ni}(\mathrm{OH})_{2}(\mathrm{c})$. Thus, their concentrations were not simply controlled by solubility equilibria of $\mathrm{Ni}(\mathrm{OH})_{2}$ (c). We speculate that the high final $\mathrm{Ni}^{2+}(\mathrm{aq})$ concentrations in the Figure 5a experiment resulted from the competitive displacement of sorbed $\mathrm{Ni}^{2+}$ by Fe(II)(aq), while those in the Figure 5b experiment resulted from this same process occurring in combination with topotactic conversion to magnetite with concomitant fixation of $\mathrm{Ni}$ in the spinel structure. The magnetite formation in the experiment of Figure $5 b$ was facilitated by the presence of AQDS. We suspect that sorption of $\mathrm{Ni}^{2+}$ to the biogenic magnetite was minimal due to the high Fe(II)(aq) concentrations and the low divalent metal complexation strength of the magnetite surface (49).

In the studied described here in, Ni was shown to inhibit dissimilatory microbial reduction of amorphous iron oxide via abiotic mechanisms, but the presence of other compounds such as humic acids or phosphate significantly modified the extent of bioreduction, metal solubility, and the suite of biominerals formed. AQDS, previously used as a model of humic acid quinone components, facilitated the immobilization of $\mathrm{Ni}$ within the crystal structure of biogenic magnetite. Accurate predictions of the biogeochemical behavior of trace metals in surface waters or groundwaters requirethorough knowledge of the aqueous and solid-phase geochemical properties of the system in addition to the microbial processes.

\section{Acknowledgments}

This research was supported by the Natural and Accelerated Bioremediation Research Program (NABIR), Office of Biological and Environmental Research, U.S. Department of Energy (DOE). Pacific Northwest National Laboratory is operated for the DOE by Battelle Memorial Institute under Contract DE-AC06-76RLO 1830. We thank Alice Dohnalkova for excellent assistance on the HRTEM analyses and David Boone(Portland StateU niversity) for providing S. putrefaciens CN32 to usfrom the SubsurfaceM icrobial CultureCollection.

\section{Supporting Information Available}

Mössbauer spectrum and XRD of unreduced NiHFO, concentrations of total Feand $\mathrm{Ni}$ in 0.5 and $5.0 \mathrm{~mol} / \mathrm{L} \mathrm{HCl}$ extracts of bioreduced NiHFO, and transmission electron microscopy images of bioreduced NiHFO (4 pages). This material is availablefree of charge via thel nternet at http:// pubs.acs.org.

\section{Literature Cited}

(1) Cornell, R. M.; Schwertmann, U. The Iron Oxides; VCH: New York, 1996

(2) Zachara, J. M.; Fredrickson, J. K.; Smith, S.; Gassman, P. Geochim. Cosmochim. Acta, 2001, 65, 75-93.

(3) Bousserrhine, N.; Gasser, U. G.; Jeanroy, E.; Berthelin, J. Geomicrobiol. I. 1999, 16, 245-259.

(4) Zachara, J. M.; Fredrickson, J. K.; Li, S. W.; Kennedy, D. W.; Smith, S. C.; Gassman, P. L. Am. Mineral. 1998, 83, 1426-1443.

(5) Roden, E. E.; Zachara, J. M. Environ. Sci. Technol. 1996, 30 $1618-1628$.

(6) Urrutia, M. M.; Roden, E. E.; Fredrickson, J. K.; Zachara, J. M Geomicrobiol. I. 1998, 15, 269-291.

(7) Fredrickson, J. K.; Zachara, J. M.; Kennedy, D. W.; Dong, H.; Onstott, T. C.; Hinman, N. W.; Li, S. W. Geochim. Cosmochim. Acta 1998, 62, 3239-3257.

(8) Lovley, R. R.; Phillips, E. J. P. Appl. Environ. Microbiol. 1987, 53, $1536-1540$.

(9) Ford, R. G.; Bertsch, P. M.; Farley, K. L. Environ. Sci. Technol. 1997, 31, 2028-2033.

(10) Tessier, A.; Fortin, D.; Belzile, N.; DeVitre, R. R.; Leppard, G. G. Geochim. Cosmochim. Acta 1996, 60, 387-404.

(11) Winland, R. L.; Traina, S. J.; Bigham, J. M. L. Environ. Qual. 1991, 20, 452-460.

(12) Cooper, D. C.; Picardal, F.; Rivera, J.; Talbot, C. Environ. Sci. Technol. 2000, 34, 100-106.

(13) Ainsworth, C. C.; Plon, J. L.; Gassman, P. L.; Van Der Sluys, W. G. Soil Sci. Soc. Am. I. 1994, 58, 1615-1623.

(14) Dzombak, D. A.; Morel, F. M. M. SurfaceComplexation Modeling: Hydrous Ferric Oxide; John Wiley \& Sons: New York, 1990.

(15) Lovley, D. R.; Phillips, E. J. P. Appl. Environ. Microbiol. 1986, $52,751-757$

(16) Stookey, L. L. Anal. Chem. 1970, 42, 779-781.

(17) Rancourt, D. G.; Ping, J. Y. Nucl. Instrum. Methods Phys. Res. 1991, B58, 85-97.

(18) Sidhu, P. S.; Gilkes, R. J.; Cornell, R. M.; Posner, A. M.; Quirk, J. P. Clays Clay Miner. 1981, 29, 269-276.

(19) Dong, H.; Fredrickson, J. K.; Kennedy, D. W.; Zachara, J. M.; Kukkadapu, R. K.; Onstott, T. C. Chem. Geol. 2000, 169, 299 318.

(20) Bancroft, G. M. Mössbauer Spectroscopy: An Introduction for Inorganic Chemists and Geochemists; McGraw-Hill: London, 1973.

(21) Greenwood, N. N.; Gibb, T. C. Mössbauer Spectroscopy; Chapman and Hall: London, 1971.

(22) Manning, P. G.; Ash, L. A. Can. Mineral. 1978, 16, 577-580.

(23) Mattigod, S. V.; Rai, D.; Felmy, A. R.; Rao, L. J. Solution Chem. 1997, 26, 391-403.

(24) Cornell, R. M.; Giovanoli, R.; Schneider, W. L. Chem. Technol Biotechnol. 1992, 53, 73-79.

(25) Cornell, R. M.; Giovanoli, R. Clays Clay Miner. 1989, 37, 65-70.

(26) Huyer, M.; Page, W. L. Appl. Environ. Microbiol. 1989, 171, 40314037.

(27) Lovley, D. R.; Phillips, E. J. P. Environ. Sci. Technol. 1992, 26, 2228-2234.

(28) Lovley, D. R.; Coates, J. D.; Blunt-Harris, E. L.; Phillips, E. J. P.; Woodward, J. C. Nature 1996, 382, 445-448.

(29) Lovley, D. R.; Fraga, J. L.; Blunt-Harris, E. L.; Hayes, L. A.; Phillips, E. J. P.; Coates, J. D. Acta Hydrochim. Hydrobiol. 1998, 26, 152157.

(30) Hering, J. G.; Stumm, W. In Mineral-Water Interface Geochemistry; Hochella, M. F., White, A. F., Eds.; Mineralogical Society of America: Washington, DC, 1990; Vol. 23, pp 427-465.

(31) Biber, M.; Dos Santos Afonso, M.; Stumm, W. Geochim. Cosmochim. Acta 1994, 58, 1999-2010.

(32) Myers, C. R.; Myers, J. M. I. Bacteriol. 1992, 174, 3429-3438.

(33) Myers, C.; Myers, J. Biochim. Biophys. 1997, 1326, 307-318.

(34) Lovley, D. R.; Phillips, E. J. P. Appl. Environ. Microbiol. 1988, $54,1472-1480$.

(35) Arnold, R. G.; DeChristina, T. J.; Hoffman, M. R. Biotechnol. Bioeng. 1988, 32, 1081-1096.

(36) Newman, D. K.; Kolter, R. Nature 2000, 405, 94-97. 
(37) Urrutia, M. M.; Roden, E. E.; Zachara, J. M. Environ. Sci. Technol. 1999, 33, 4022-4028.

(38) Jambor, J. L.; Dutrizac, J. E. In Process Mineralogy; Hagni, R. D., Ed.; The Minerals, Metals and Materials Society: Warrendale, PA, 1995; pp 239-249.

(39) Cornell, R. M. Clays Clay Miner. 1988, 23, 329-332.

(40) Tronc, E.; Belleville, P.; Jolivet, J. P.; Livage, J. Lanqmuir 1992, 8, 313-319.

(41) Couling, S. B.; Mann, S. L. Chem. Soc. Chem. Commun. 1985, $1713-1715$

(42) Sidhu, P. S.; Gilkes, R. J.; Posner, A. M. J. Inorg. Nud. Chem. 1978, 40, 429-435.

(43) Diamandescu, L.; Mihaila-Tarabasanu, D.; Teodorescu, V.; Popescu-Pogrion, N. Mater. Lett. 1998, 37, 340-348.

(44) Fouillac, C.; Criaud, A. Geochem. J. 1984, 18, 297-303.
(45) Tamura, H.; Matijevic, E.; Meites, L. L.Colloid InterfaceSci. 1983, 92, 303-314.

(46) Zachara, J. M.; Cowan, C. E.; Resch, C. T. Geochim. Cosmochim Acta 1991, 55, 1549-1562.

(47) Tamura, H.; Katayama, N.; Furuichi, R. J. Colloid Interface Sci. 1997, 195, 192-202.

(48) Tamura, H.; Furuichi, R. . . Colloid InterfaceSci. 1997, 195, 241249.

(49) Criscenti, L. J.; Sverjensky, D. A. Am. J. Sci. 1999, 299, 828-899.

Received for review July 18, 2000. Revised manuscript re ceived November 13, 2000. Accepted November 16, 2000.

ES001500V 